\title{
AN ANALYSIS ON MURABAHAH APPLIED IN \\ BANK TABUNGAN NEGARA (BTN) SYARIAH MALANG BRANCH
}

By :

BARIDA HIDAYATI

\begin{abstract}
This research is based on the good performance of murabahah financing on Indonesia Islamic Banking. The murabahah is one of the financing products that based on the Islamic trading principle which is preeminence the honest between the seller and the buyer. According to it, this research investigates the transparency process in BTN Syariah including the transparency pre-akad, akad and after akad.

This research is designed using qualitative method. To collect the data the researcher uses interview, observation and documentation, while for verifying data the researcher uses triangulation.

The result of this research explains that murabahah transparency is done well in BTN Syariah Malang Branch, even it is found many problem on it. The problem found is identified on pre akad, on akad and before akad. the problem on pre akad is found around the bank explanation and the client understanding, the akad problem is found around the akad reading and the akad signing while the after akad problem is found around the accelerate payment formula.
\end{abstract}

Keywords : Murabahah, Transparency 


\section{A. THE RESEARCH BACKGROUND}

Based on the Islamic Banking Statistic August-November 2006 browsed from Central Bank of Indonesia, murabahah not only dominated whole financing product but also increasing rapidly month by month. Mu'alim wrote that this performance happened in almost Islamic country around the world such as Malaysia (86.2\%), Bahrain (69.9\%), Bangladesh $(61.0 \%)$, Emirate $(96.3 \%)$, Jordan (43.9\%), and Turkey (17.3\%). The majority percentages of this kind of financing are used for consumptive activity. More than $90 \%$ of murabahah financing is deals with an installment purchase of motor payment (Modal Magazine, 2003; 82).

Bambang (Riaupos.com; 2005) says that murabahah surpasses other products on three points. First it is implicable; second it is predicable, third it is unnecessary to know the customers deeply

Those descriptions about murabahah domination are completed by Triyuwono in his journal (2000) that informs about the costumer's perception and preference on Islamic banking. He says that the costumer consumes Islamic bank's product rationally. This reason makes the costumer consider about the advantages they will get.

According to the preliminary survey, Bank Tabungan Negara Syariah (BTNS) has murabahah domination in its financing composition. Besides, it has been identified as one the bank that specifies the property which uses murabahah as the akad (agreement). This is the distinctive features of BTNS that distinguishes it from other sharia bank. Those become the reasons why the researcher prefers it to be the research object.

\section{B. THE RESEARCH PROBLEM}

Based on the first chapter above, the significant problems of this research are formulated in the questions;

1. How is the application of murabahah and its transparency in BTN Syari'ah Malang branch? 
2. What problems are faced by BTN Syari'ah Malang in applying murabahah and how is the solution?

\section{THE RESEARCH OBJECTIVE}

Related to the focused problem elaborated in this research, the objectives of the research are:

1. Describing the application of murabahah and its transparency in BTNS Malang branch

2. Identifying problems and recommending its solutions in applying murabahah at BTNS Malang Branch

\section{SCOPE AND LIMITATION}

To simplify the analysis, the researcher sets some scope and limitation on this research. The scope and limitation is focused on the financial transparency process of murabahah categorized previously, on and after akad. The researcher takes the transparency because it is strongly related with the murabahah main concept that told the seller to divulge the main cost, the margin and the related expenses to the buyer. The researcher determines the akad as the standard process because the akad is an instrument which distinguishes Syariah banking with conventional banking

\section{E. THE RESEARCH SIGNIFICANCE}

1. For academician :

This research will enrich the reference on murabahah as guide to conduct further researches on similar field.

2. For the related instances:

This research helps them to know more the potential of murabahah finance. It also can be used as one of measuring standard on Islamic financial product. Furthermore, they can identify what problems are faced by Islamic banking in murabahah practice. 


\section{F. REVIEW OF THE RELATED THEORY}

\section{A.1 Murabahah}

Utsmani (2006) says that Murabahah is a particular kind of sale where the seller mentions the cost of the sold commodity he has incurred, and sold it to other person by adding some profit or mark-up thereon.

Murabahah was originally an exchanging transaction in which a buyer purchases items from a seller at a specified profit margin payable to the seller (www.bankislam.com)

On DSN fatwa (2000) the meaning of murabahah is some transactions where bank (as the seller) sells some commodity with the main price added with the mark up. This bank has to inform the main price, the mark up and the related expenses honestly.

Based on the definitions above murabahah concluded as a kind of transaction that the seller has to divulge the main price, the mark up and the related expenses to the buyer accurately

The fundamental law of murabahah was written in holy Quran on Al Baqarah 275 and An Nisa' 29 either in hadith profiled by Ibnu Majjah and Baihaqi and ijma (general agreement) MUI Fatwa no 04/DSN-MUI/IV/2000 that describe about the legality of the murabahah

The specific regulation about murabahah is covered by On Meezanbank as follow

a) The subject of sale must exist at the time of the sale.

b) The subject matter should be in the ownership of the seller at the time of sale.

c) The subject of sale must be in physical or constructive possession of the seller when he sells it to another person. Constructive possession means a situation where the possessor has not taken physical delivery of the commodity yet, it has come into his control and all rights and liabilities of the commodity are passed on to him including the risk of its destruction.

d) The sale must be instant and absolute. 
e)The subject matter should be a property having value.

f) The subject of sale should not be a thing used for an un-Islamic purpose.

g) The subject of sale must be specifically known and identified to the buyer.

h) The delivery of the sold commodity to the buyer must be certain and should not depend on a contingency or chance.

i) The certainty of price is a necessary condition for the validity of the sale.

j) The sale must be unconditional.

MUI elaborates the detail ruler for murabahah including the murabahah discount, murabahah advance payment, murabahah amount reduction, murabahah reagreement, murabahah settlement and murabahah rescheduling payment as follow ,
a) no 04/DSN-MUI/IV/2000 on murabahah,
b) no 16/DSN-MUI/IX/2000 about Discount of Murabahah,
c) no 13/DSN-MUI/IX/2000 about Advance payment,
d) 46/DSN-MUI/II/2005 about Reduction Amount of Murabahah,
e) no 49/DSN-MUI/II/2005 about Reagreement of Murabahah,
f) no 47/DSN-MUI/II/2005 about Settlement of Murabahah,
g) no 48/DSN-MUI/II/2005 on Rescheduling Of Murabahah Payment

\section{G. RESEARCH METHOD}

The research is designed with qualitative method specified to descriptive method, this research located at Bank Tabungan Negara (BTN) Syariah, Jln. Ade Irma Suryani no 24 Malang. To collect the data, the researcher uses participant observation, unstructured interview and documentation after the data is collected the researcher use triangulation to verify the data 


\section{H. THE PORTRAIT OF BTN SYARIAH MALANG BRANCH}

Actually, BTNS is one of the BTN Conventional units. Therefore, BTNS is named by BTN Syariah Branch Office (SBO), but in this journal BTN Syariah Branch office will wrote as the Bank Tabungan Negara Syariah only (BTNS) the opinion of this Islamic unit appears at the stakeholder general meeting on 16th of January 2004. The syariah unit established not only as one of the BTN equipment to get the market share but also as the existence of its grace religious activity. Furthermore, BTN Syariah is established in order to support the economic government policy specifically and to take apart of the Indonesia development generally.

The beginning of 2005 BTN established at least five syariah branch offices in several cities, and established two additional offices at the end of the 2005. BTNS Malang branch was established concurrently with BTN Solo on $1^{\text {st }}$ of December 2005. It is located at Jln. Ade Irma Suryani no 2-4 Malang on the beneath floor of BTN Conventional building. In Its opening ceremony the director of BTN Iqbal Latanro signed on a particular inscription which was also followed by mayor deputy of Malang Drs. Priyo utomo and KH Ali Maschan Musa (the head of PWNU of East Java).

1. Vision and mission

The Vision of BTNS Malang is to become the business strategic unit in notable and healthy BTN landing on Islamic financial services in order to keep on accentuate the major benefits

2. The Mission of BTN Syariah Malang are :

1. Supporting the BTN's profit achievement goal,

2. Giving the best financial service quality in financing properties and other related products in order to satisfy the client to achieve the expected market share,

3. Performing the syariah banking management to raise the BTN's resilience on business space alteration and the share holder value,

4. Balancing the repletation of whole stake holder's consequences and giving the excitement to the clients and employees 
BTNS has 340 products of financing and 801 products of funding as the following.

Table 4.2

Existed Funding Products

\begin{tabular}{|c|c|c|c|c|c|}
\hline \multicolumn{2}{|c|}{ Syariah demand deposit } & \multicolumn{2}{|c|}{ Batara Saving } & \multicolumn{2}{c|}{ Syariah Deposito } \\
\hline Unit & Nominal & Unit & Nominal & Unit & Nominal \\
\hline 27 & 332.000 .000 & 705 & 3.268 .000 & 69 & 5.365 .000 \\
\hline
\end{tabular}

Source: realization product report at B TNS Malang branch 2006

Table 4.3

Existed Financing Products

\begin{tabular}{|l|l|l|l|l|l|l|l|}
\hline \multicolumn{3}{|c|}{ Murabahah } & \multicolumn{4}{c|}{ Mudharabah } \\
\hline \multicolumn{2}{|c|}{ KPR Syari'ah } & Multiguna Syari'ah & \multicolumn{3}{c|}{ Musyarakah } & \multicolumn{2}{c|}{ Mudharabah } \\
\hline Unit & Nominal & Unit & Nominal & Unit & Nominal & Unit & Nominal \\
\hline 311 & Rp25,334,550,000 & 20 & Rp469,250,000 & 8 & Rp2,367,195,746 & 1 & Rp100,000,000 \\
\hline
\end{tabular}

Source: realization product report at BTNS Malang branch 2006

From the table above, it is found that the funding is dominated by saving product (705 units), this is caused by the high value of the financing product. Here, the client who takes financing product (supplier or user) has to have account in BTNS. Most of the clients do the transaction from their account including the BTNS' debt settlement on the supplier and the client's debt financing settlement on the BTNS.

Murabahah has totally dominated the financing product for four months respectively as it is the only product published by BTNS. However, in the future BTNS realize other financing (musyarakah and mudharabah) even though the murabahah is still favoured.

\section{FACT FINDING}

1. Explanation and understanding

From the source triangulation, this item has been verified well. Even client interview result does not support the data. Further, the client told that he did not know what murabahah is, they just know how much they must pay for settling the debt. This is caused by the client's considerations 
on interest rate advantage. The client pays more attention to interest percentage than profit margin amount.

2. Mechanism of murabahah

From the source triangulation, this item has been verified well and becomes a valid data. The interview result states that murabahah mechanism is begun from the clients/supplier proposal processed in 3 days by the account officer (AO). After the proposal is processed, the AO will inform the proposal approval, then BTNS will held the akad among supplier, BTNS and the user (client).

When those interview data results are crosschecked with documentation and observation results, they were supporting each others information. From those triangulation methods, those data are marked as valid data.

3. Advance payment

This information is gathered from supplier, client and BTNS. Each of them mentions the same statement that advance payment is paid to the supplier. After verified in source, the data is verified in technique. In that verification, all techniques supports the information except that from documentation. The documentation (the agreement sheet in fourth and eighth paragraph) said that the advance payment has to be paid to the bank. However, the data is still valid. Based on the researcher's confirmation the advances payment is paid to the supplier directly in order to keep the process effective and efficient.

4. The murabahah object

This information is gathered from the documentation and observation. From those methods the object can be described as having rightful on Islamic regulation object, not for illicit motif and having money value.

5. The contract

The contract consists of the maturity date, the financing tenor, the amount of financing and the agreement schedule which are decided by BTNS. Those items support each other, therefore the datum is valid and there is no problem in source and technique triangulation test. 
6. The akad mechanism

From the triangulation tests, this datum has been verified well. There are no differences between the techniques and the sources of data. All of the collected information state that there is no standard mechanism for akad. Therefore, the datum is valid.

7. The collateral

From the triangulation tests, this datum has been verified well. There are no differences between the techniques and the sources data result. All of the collected information state that the collateral consists of the land certificate and the building permission (IMB). Based on that description, this datum becomes valid.

8. Cash discount

This cash discount datum is obtained from the resercher's interview with BTNS operational head. He says that all the cash discount is returned to the buyer. BTNS never takes the discount. Even there is no other data supporting it, this datum is categorized as valid. The reason is the interviewee is the direct executants of this cash discount.

9. The settlement

This datum consists of installment debt payment, acceleration payment and extra payment. The first two are gathered from interview, observation and documentation. There is no datum available for extra payment because there is no extra payment happened in BTNS Malang. The installment debt payment is one way to settle the financing debt in common, while acceleration payment is one way to settle all the outstanding financing debt in particular time. Both of the data support each other in source triangulation and in technical triangulation. Therefore, this data are valid.

10. The arrears

From the information gathered, the clients who run up the instalment have to pay the penalty; it is regulated in agreement sheet in first provision. The arrears information is collected from interview, 
documentation and observation. It is verified well both in source triangulation and method triangulation. Therefore, this datum is valid.

11. The adjudication

The adjudication data is gathered from interview and documentation. The researcher did not find the adjudication data from the observation process. It is because there is no adjudication happened in BTNS. BTNS chooses the auction way to adjudicate the debt financing. This information is stated by the operational head and supported by the agreement sheet in 14, 15, 16 provision. The description above is one reason for the researcher to mark the datum valid.

12. The akad conversion

The datum of akad conversion is obtained from interview. There is no other data gathered from documentation nor observation. The interview informs that akad conversion is regulated in BTNS. There is no client or case stipulation for the akad conversion.

13. The akad rescheduling

The akad rescheduling is obtained from interview. There is no other data gathered from documentation nor observation. The interview informs that akad rescheduling is not regulated in BTNS. There is no client or case stipulation for the akad rescheduling

\section{J. DISCUSSION}

According to the previous categorized, the fact finding describe with three category namely pra $a k a d$, on $a k a d$ and after $a k a d$

1. Pra akad

interview results show the pre akad transparency well. The client interview results show the client's understanding about the bank's explanation. According to Fitri, the bank firstly explains about the differences between bank mark up and interest. This is done in order to replace the client's mindset about the interest in conventional bank with the profit-share (markup on murabahah) in 
addition the CS also gives the explanation about the requirement, the expenses, the maturity date and the margin clearly. The explanation is not only given by CS but also by AO. Further the $\mathrm{AO}$ explains more specifically than CS, the AO explains the margin of the proposed financing, the insurance, the expenses for akad, the arrears fine and others. This explanation is done by the AO when the client-financing proposal is approved and before the day akad is done.

From the interview, observation and documentation the researcher conclude that the murabahah transparency is done well in BTNS Malang, it shown from the pre akad observation. The Account Officer (AO) explain clearly about the debt, expenses and the margin. To measure the client's understanding the AO always explain when he want to do akad. Beside , the researcher find some explaining problem in applying murabahah. The problem that the researcher found in the field is the client understands. Some of the clients do not know about the murabahah is. They just remember about the interest rate they take. Actually, the interest rates they mean are the margin taken by BTNS. This indicates that the clients still assume that the margin is similar with the interest rate in conventional bank. Further, the client states the reason of choosing BTNS Malang as the financer; they say that BTNS Malang has flexible, easier and transparent procedure. This indicates that the choice is based on the economic advantages. This is in contrast with the view of Triyuwono (2000) that states the reason of mentioned by economic advantages is factories while individually more on spiritual. This kind of explanation fails caused by using percentages formula to explain the murabahah margin, in order that some of client still assume that margin (profit sharing) as same as interest. Both mark up is different each other when we talk about interest percentage it based on the money debt amount, but 
if we talk about margin it based on the profit-sharing ratio based on the profit obtained (Antonio, 2001)

\section{On akad}

In the opening the $\mathrm{AO}$ sends on greeting and says that they want to do akad that day, then the AO explains about murabahah and wakalah akad, continued by the explanation by the notary. After both explanations, the bank verifies clients understanding about the explanation. If the client understood well, the akad will continue on the akad signing. The akad signing consists of murabahah, wakalah and notary document signing. After the entire document is signed, the bank after closes the akad by praying but usually the akad is only closed by the closing utterance.

On the akad the researcher found that the document signed by the client is legitimated by notary. However, in fact-finding all the akad document is read by bank Account Officer. This case is risk able because the mistakes in reading akad become the bank's responsibility. According to the legimatation, all akad must be the notary responsibility. The researcher also found a problem in akad, and ijab-qobul (take-give). As we know akad in syariah bank is one of financing instrument that differs the syariah bank with conventional bank. When ijab-qabul of akad is done in written document, it seems like the conventional agreement.

In addition, the researcher has found some problem in signing. Based on the fact finding, akad does not have standard mechanism. The signing between Murabahah Akad, Wakalah and notary document is done irregularly. At the time the murabahah is signed before wakalah and document notary, the document notary is signed before murabahah and wakalah. Actually the first signing is on Wakalah before Murabahah and notary document. This refers to its function as one of the letter of authority in purchasing. Here the bank gives the authority to purchase 
the commodity to the client as the agent of bank. So the murabahah is not signed before the bank gives the authority on the wakalah sheet.

\section{After akad}

Most of the after akad transparency fact-finding is obtained from documentation which is on the settlement of financing. The settlement is divided into three kinds of settlement, install payment; accelerate payment and extra payment. Nevertheless, the transparency analyses just describe the install payment and accelerate payment.

a. The transparency on install payment

The transparency on install payment showed when BTNS gives the installment schedule to the client. From it the clients know exactly about the settlement clearly, including the remaining debt, and margin. The monthly installment formulated as below

Table 4.5

Monthly Instal Payment

\begin{tabular}{c|c} 
Monthly instalment $=$ & Main debt $+\{($ main $x$ margin $) \times$ tenor $\}$ \\
\cline { 2 - 2 } & tenor (in month $)$
\end{tabular}

b. The transparency on accelerate payment

Based on the payment tenor, this accelerate payment is divided into two kinds of acceleration; it was acceleration under five years and acceleration more than five years.

On the field, the researcher found one client who accelerates her payment. She says that BTNS was transparent enough for the debt procedure settling. When she proposes to settle the debt forward, the AO explains the detail nominal that must be paid by the client. The nominal involves the outstanding, the double margin and the related expenses. The counting formula can be noted as a following, 
Table 4.6

Accelerate Payment Formula

\begin{tabular}{|ll|}
\hline The nominal to be paid & $=$ (outstanding debt + margin $)+(2 \times$ margin $)$ \\
Saving balance nominal & $=$ Rp. $\mathrm{X}$ \\
Total payment & $=$ Rp. $\mathrm{Y}$
\end{tabular}

Based on the data collected the researcher found many problems in after akad transparency such as in the accelerate payment. Even the transparency is done well enough but the BTNS still applies some addendum that may cause the usury assumption. This becomes a problem, shown the multiple addendum which has been paid by the client in accelerate payment. The outstanding debt must be paid without any addendum like multiple margin required in BTNS. Based on the fatwa MUI no.46/DSN-MUI/II/2005 the cash discount is given to the client who has paid the debt rapidly. Here the BTNS does not give some cash discount but take some addendum from the debt.

The murabahah transparency application in BTNS is proven to be the best in transparency services. It is compatible with the definition of murabahah that emphasizes the transparency of the price between the seller and the buyer. The transparency has strong connection with the honesty in trading as it is one of the honesty manifests. The honesty is one important thing on the transaction. Such as what Yusuf Qardhawi $(2001 ; 293)$ states, the honesty as one of the main faith of morality and the dominant prophet characteristic. Further, the honest transaction brought the blessing on trading, such as what mentioned in Prophet Muhammad hadith

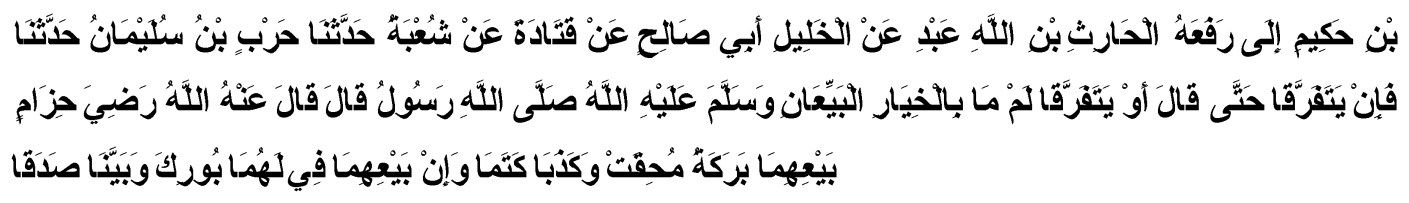


"The seller and the buyer have a right to decide the alternative as long as both disassociate, their transaction is blessed when both of them are honest and explain the truth but when they lie and hide the truth maybe they probably will get the profit but they fade the blessing from it." (Bukhari bab buyu no 1937)

The problems found are almost on the technical problems such as the client explanation-understanding problem, the responsibility of the document akad legality problem and the accelerate payment problem. These problems are due to the BTNS being established one year ago therefore it still needs many improvements.

\section{K. CONCLUSION}

Based on all descriptions and analysis this research result can be conclusion is as follow

1. The application of murabahah in BTNS Malang before, during and after akad was transparent enough

2. There are some problems in murabahah application namely
a. Insufficient clients understanding about the murabahah concept
b. The responsibility of the akad document legality and the akad signing
c. The addendum on the accelerate payment

\section{RECOMMENDATION}

This recommendation refers to the related institutions (BTNS Malang) and the next researchers. Other from two side above the researcher describe about the strength and the weakness of this research on this discussion

1. Recommendation for related institutions

a. To solve the insufficient clients understanding, the bank is supposed to give more explanation about murabahah concept to the clients. The explanation is not only on the nominal or the economic advantages but also that involving knowledge of syariah banking.

b. To prevent the disputes, the researcher recommends the entire document including akad murabahah and wakalah is read by the notary. 
However the bank still has to verify the clients understanding on the bank's document that is read by the notary.

To keep the akad confirmed; the researcher recommends the standard akad as follow steps

1) The akad opening with salam by $\mathrm{AO}$

2) The explanation about the akad, the position of seller and buyer, and the object by $\mathrm{AO}$

3) Reading murabahah, wakalah, and notary document by notary

4) Verifying the client understanding and give some time to the client for asking.

5) Signing wakalah akad

6) Signing murabahah akad

7) Signing document notary

8) Ijab qobul between the client and the bank

9) Closing with praying, salam and some suggestion by bank

c. To keep away from the usury assumption, the researcher recommends the accelerate formula as follow,

1. Accelerate payment $=$ Main outstanding debt (at the month) + margin

This alternative has advantages, such as the first alternative is keeping way from the usury assumption effectively and made the client more convenient indirectly it will increase the profit they will get.

2. The advantages and weakness of research

This thesis examines whole murabahah application from pre adoption until the settlement, beside that it use research tools optimally such as recording akad activities (displayed on video), proof of interview. The weakness of this research can be found on only focused problem (murabahah transparency applied in BTNS Malang branch office), the research does not have any indicator to built data from field, this make the data result too large and impossible to analyze deeply. Event this 
research does not have any indicator but the data collected checked tightly with two kind of triangulation,

3. Recommendation for the next researcher

Based on the fact-finding on this research, many problems have to be researched, such as,

a. To know the murabahah application from Islamic law perspective the researcher can focus on the murabahah and akad mechanism.

b. To know the murabahah socialization from the marketing perspective the researcher can focus the research on the client perception

c. To know about the murabahah from the syariah accountancy, the researcher can focus on the murabahah inventory.

d. Recommend to next researcher to use research indicator in order to make the research more detail and accurate 


\section{BIBLIOGRAPHY}

Central Bank of Indonesia, Islamic Banking Statistics-August 2006, www.bi.go.id

Antonio, Syafi'i 2001. Bank Syari'ah Dari Teori Ke Praktek, Gema Insani Press, Jakarta

Memahami murabahah, http;//www.riaupos.com/web-riau pos online

Mu'alim, Amir, 2004, praktek pembiayaan bank syari'ah dan problematikanya, MSI UII.net

Qardhawi, yusuf, 2001 peran nilai dan moral dalam perekonomian islam, rabbani press, Jakarta

Taqi, Maulana Usmani, Musharakah $\mathcal{E}$ Mudarabah, http://www.darululoomkhi.edu.pk/fiqh/islamicfinance/murabaha.htm $\underline{1}$

Triyuwono, iwan, 2000, Potensi, Preferensi dan Perilaku Masyarakat Terhadap Bank Syari'ah di Wilayah Jawa Timur, Centre for Business \& Islamic Economics

Studies Faculty of Economics-Brawijaya University dan Bank IndonesiaJakarta

http://www.islamic-finance.com/item_murabaha_f.htm 